\title{
THE EFFECT OF FINANCIAL PERFORMANCE AND DIVIDEND POLICY ON CUMULATIVE ABNORMAL RETURN
}

\author{
Yayuk Sri Rahayu1, Guntur Kusuma Wardana ${ }^{2}$ \\ 1,2Universitas Islam Negeri Maulana Malik Ibrahim Malang, Indonesia
}

$凶$ Corresponding Author:

Nama Penulis: : Yayuk Sri Rahayu

E-mail: yayuk@pbs.uin-malang.ac.id

\begin{abstract}
The purpose of this study was to determine the effect of financial performance and dividend policy on Cumulative Abnormal Return for company shares in Jakarta Islamic Index. The population was all company stocks listed on The Jakarta Islamic Index from 2009 to 2018. The samples were selected by purposive sampling with the criteria the companies were consistently included in JII (not delisted and relisted) during the 2009-2018 period and those that met the criteria were five companies. Financial performance was proxies by Earning per Share, Price Earnings Ratio, Current Ratio, and Return on Equity. Meanwhile, dividend policy was proxies by the Dividend Payout Ratio. This research type was quantitative by using the panel data regression method. The results showed that Earning per Share effect on Cumulative Abnormal Return, while the Price Earnings Ratio, Current Ratio, Return On Equity and Dividend Payout Ratio variables had no effect on Cumulative Abnormal Return. The implications of this research for other parties consists of scientific development, especially in the field of financial management, and can be an input for investors in investing in shares on the Indonesia Stock Exchange (IDX) so that it can have a positive impact in the form of dividends or capital gains to investors. And can be used as a reference for further researchers by adding other variables that are not included in this study.
\end{abstract}

Keywords: Financial Performance; Dividend Policy; Cumulative Abnormal Return

\section{Abstrak}

Tujuan penelitian ini adalah untuk mengetahui pengaruh kinerja keuangan dan kebijakan dividen terhadap Cumulative Abnormal Return saham perusahaan di Jakarta Islamic Index. Populasi dalam penelitian ini adalah seluruh saham perusahaan yang terdaftar di Jakarta Islamic Index tahun 2009-2018. Pengambilan sampel dilakukan secara purposive sampling dengan kriteria perusahaan secara konsisten masuk dalam JII (tidak delisting dan relisted) selama periode 2009-2018 dan yang memenuhi kriteria. kriteria lima perusahaan. Kinerja keuangan diproksikan dengan Earning per Share, Price Earning Ratio, Current Ratio, dan Return on Equity. Sementara itu, kebijakan dividen diproksikan dengan Dividend Payout Ratio. Jenis penelitian ini adalah kuantitatif dengan menggunakan metode regresi data panel. Hasil penelitian menunjukkan bahwa Earning Per Share berpengaruh terhadap Cumulative Abnormal Return, sedangkan variabel Price Earning Ratio, Current Ratio, Return On Equity dan Dividend Payout Ratio tidak berpengaruh terhadap 
Cumulative Abnormal Return. Implikasi dari penelitian ini bagi pihak lain terdiri dari pengembangan keilmuan khususnya di bidang manajemen keuangan, dan dapat menjadi masukan bagi investor dalam menanamkan saham di Bursa Efek Indonesia (BEI) sehingga dapat berdampak positif bagi perekonomian. bentuk dividen atau capital gain kepada investor. dan dapat dijadikan acuan bagi peneliti selanjutnya dengan menambahkan variabel lain yang tidak termasuk dalam penelitian ini.

Kata kunci: Kinerja Keuangan; Kebijakan Dividen; Pengembalian Abnormal Kumulatif

\section{INTRODUCTION}

The financial ratios factors are used by investors mainly to make fundamental analysis in the investment world. Investors can see the company performance through financial ratios. Investors can make investment decisions by conducting performance analysis. Also, an important factor that should be concerned is the stock price when investing in companies listed on the capital market. The share price generally reflects the value of a company in public eyes (Samsuar, 2017).

The Islamic capital market shows progress along with the increase in the index in JII. The emergence of JII in the Islamic capital market can be used as an alternative to investing in securities consistent with Islamic sharia for Muslim investors. The shares listed in JII have gone through the screening stage, where the JII stock selection process is done by DSN-MUI and Financial Services Authority (OJK). There are only 30 of the most liquid sharia stocks that can join into JII (IDX.co.id). Besides, shares listed on JII are referred to as Islamic blue-chips (Yuliawati \& Darmawan, 2019).

In the investment business, financial ratios are the main factor used by investors in conducting fundamental analysis. Through financial ratios, investors can find out the performance of a company. Based on this performance, investors can make investment decisions. Also, the stock price is an important factor that investors need to pay attention to when investing in companies listed on the capital market. Share prices generally reflect the value of a company in the eyes of the public (Samsuar, 2017). The capital market has an important role in the Indonesian economy. This is because the capital market carries out two main functions, namely as a means of investment/business funding and as a means for companies to obtain sources of funds from investors.

A company's dividend policy will also affect abnormal returns. Higher dividend value can increase the share price because investors have certainty about their investment. A high stock price will affect a positive return. The high stock return will affect on higher abnormal return value (Ulfah \& Paramu, 2017). Therefore, a higher dividend value can increase the stock 
price and return distribution to investors. It can attract investors to invest in companies that are classified in JII.

Some previous studies have had different results where (Bakar \& Rosbi, 2019) examined abnormal returns which state that the company's performance is negative compared to the market, so that market performance is better than the company's performance. This research shows that the abnormal return value according to the market is negative by using the Market Adjusted Cumulative Abnormal Return (MACAR) method. So, it can be concluded that company performance does not have a significant effect on market adjustment cumulative abnormal returns. In addition, research conducted by (Ulfah \& Paramu, 2017) stated that the DPR had no significant effect on Abnormal Return. Meanwhile, different research results were conducted by (Utami \& Murwaningsari, 2017) stated that the Dividend Pay-out Ratio has a significant effect on stock returns.

Based on the theory and/or research gap and phenomena, the research objective of this study is to determine the effect of financial performance and dividend policy on Cumulative Abnormal Return (CAR) of company shares in the Jakarta Islamic Index.

\section{LITERATURE REVIEW}

\section{Financial performance}

Financial performance is a description of the company's financial condition in a certain period related to funds rising and the expenditure measured by capital adequacy, liquidity and profitability indicators (Jumingan, 2006). The company's financial performance is a company achievement in a certain period to reflect the health level of the company (Sutrisno, 2009). Therefore, financial performance is a description of the company's financial condition analyzed with financial analysis tools. It can show the financial condition of a company to reflect the work performed in a certain period.

\section{Financial Ratios}

Financial ratios are activities to compare the financial statements by dividing one number by another. The interested parties can find the company's financial ratios performance in a certain period. This study uses the ratios of Earning per Share (EPS), Price Earning Ratio (PER), Current Ratio (CR) and Return on Equity (ROE).

\section{Dividend Policy}

A dividend policy is a company decision to share the percentage of profit to shareholders in form of dividends. The percentage of profit paid to 
shareholders in cash reduces the retained earnings of a company; the dividend decisions involve financing decisions (Horne, 1994). The lower the dividend value, it will cause concern for shareholders. Also, low dividends will encourage investors to sell their shares. It can decrease the company's stock price and affecting the returns. The small actual return value will affect the low abnormal return value. The dividend policy is proxied by the Dividend Payout Ratio (DPR).

\section{Abnormal Return}

Stock return is one factor to motivate investors to invest and a reward for an investor to bear the risk of the investment (Tandelilin, 2010). An unreasonable profit is called an abnormal return. Abnormal return can be interpreted as an excess of return that occurs against normal returns, because of new events or information that will change the value of a company (Jogiyanto, 2010). Therefore, it can be interpreted that return is an indicator to test market efficiency. Meanwhile, abnormal return is the difference between the actual return and the expected return.

\section{Jakarta Islamic Index (JII)}

The Jakarta Islamic Index (JII) is one of the stock indices in Indonesia. JII calculates the average stock price index for stocks that meet sharia criteria. Determination of criteria for selecting shares in JII involves the Sharia Supervisory Board of PT Danareksa Investment Management (PT. DIM). Therefore, companies listed in JII distribute returns to investors that free from usury. This is consistent with surah al-Baqarah verses 278-279, which means:

". O you who believe! Fear Allah, and forgo what remains of usury, if you are believers. If you do not, then take notice of a war by Allah and His Messenger. But if you repent, you may keep your capital, neither wronging, nor being wronged."

The verse explains that companies listed on JII do not have usury activities. The usury is forbidden by Allah and His Messenger. In addition, companies in JII are prohibited to produce goods that contain haram (forbidden) elements such as alcoholic liquor, because the principle of halalness in transactions on Islamic stocks is the most important requirement.

\section{The Relationship between Earning Per Share (EPS) and Stock Return}

Earning per share (EPS) is a benefit to shareholders from each share they own (Fahmi, 2012). The income changes for a share can cause changes 
in stock returns. Investors can see the company's future profit prospects from the EPS variable. High EPS will invite more investors to buy the shares, which can cause a high share price (Sasongko \& Wulandari, 2006). The higher the EPS value in the company can make shareholders lucky, this is because the greater the profit for shareholders. The company profit tends to increase share price. Adversely, a Lower Company's profit will decrease the share price. This will also affect changes in the company's stock returns. Therefore, the hypothesis can be formulated below.

H1.A: EPS affects CAR of shares in JII.

\section{Relationship between Price Earning Ratio (PER) and Stock Return}

PER is used by investors to measure market operations related to the issuer's ability to make profits in future. A higher growth rate of a company will increase the PER (Prastowo \& Yuliati, 2005). THE lower PER value of the company will decrease the company's stock price. The PER value is low because of lower stock price tends or higher net profit. It Higher PER value can also be interpreted as a higher company's ability to pay dividends to investors. This is one of the considerations of an investor to invest in a company. Therefore, the hypothesis can be formulated below.

H1.B: PER affects CAR of shares in JII

\section{The Relationship between Current Ratio (CR) and Stock Return}

$\mathrm{CR}$ is the ratio used to measure the company's ability to pay shortterm liabilities with the current assets (Sujarweni, 2017). The high CR value of a company indicates that the company's ability to repay short-term debt is higher. Better CR reflects the better company's performance, and the ability to meet the short-term capabilities is higher. This will increase the company's credibility in investor's eyes and increasing the company's stock return (Parwati \& Sudiartha, 2016). Therefore, higher CR can increase the stock return of the company and attracting investors to invest. Therefore, the hypothesis can be formulated below.

H1.C: CR affects CAR of shares in JII.

\section{Relationship between Return on Equity (ROE) and Stock Return}

$\mathrm{ROE}$ is a ratio to shows the level of a company's ability to earn a profit. Besides, ROE also shows the company's ability to manage its capital to generate the profits that will be distributed to preferred shareholders and common stockholders. Higher ROE indicates the company success to achieve the owner's mission. Higher ROE can influence the investors and potential investors to invest in the company. The investors will buy shares at a higher price if the ROE value of the company is expected to continue to increase and 
the company's shares will provide high returns to investors (Darsono \& Ashari, 2005). Therefore, the hypothesis can be formulated below.

H1.D: ROE affects the CAR of shares in JII.

\section{The Relationship between Dividend Payout Ratio (DPR) and Stock Return}

Dividend Payout Ratio is a ratio that shows the percentage of the company's net income to be paid to shareholders in the form of dividends (Sudana, 2015). The DPR shows the rate of return of profit distributed in form of dividends to shareholders. Lower the DPR value of the company cause shareholders to sell their shares and decrease the company's stock price and affecting the rate of return. The small actual return value can affect the low abnormal return value. Therefore, the hypothesis can be formulated below.

H2: DPR affects CAR of shares in JII.

\section{METHODS}

The population is a collection of individuals or research objects that determined the qualities and characteristics. This study population was all 75 companies' stocks listed in the Jakarta Islamic Index (JII) from 2009 to the end of December 2018. The samples were selected by purposive sampling based on certain criteria that consistent with research needs. The criteria were companies consistently entered the JII (not delisting and relisting) during the study period 2009-2018, the companies issued financial reports during the study period 2009-2018 and completed the required data. These study variables were classified into independent and dependent variables. The independent variables are EPS (X1), PER (X2), CR (X3) and ROE (X4), and DPR (X5) while the dependent variable is CAR (Y).

\section{RESULTS AND DISCUSSION}

Descriptive analysis is intended to determine the characteristics of the variables using the data of the minimum value, maximum value, average and standard deviation of the variables studied. The variables used in this study are dependent, namely, stock returns as measured in the form of Cumulative Abnormal Return (Y) and independent variables in the form of Earning Per Share (X1), Price Earnings Ratio (X2), Current Ratio (X3), Return On Equity. (X4), and Dividend Payout Ratio (X5). The descriptive statistical data for each research variable is shown in Table 2.

Table 2. shows the minimum CAR value is $-1.148 \%$, namely at PT. Astra International Tbk in 2012, while the maximum CAR value is $0.612 \%$, namely at PT. Kalbe Farma Tbk in 2010 with an average CAR is $0.043 \%$ and a 
standard deviation is $0.300 \%$. During the observation period, the average CAR was positive. This is because the market began to act with investor's interest to invest in Islamic stocks. Also, even though there were stock splits in several companies in JII, it did not make stock prices unstable.

Table 2. Descriptive Statistics of Behavioral Variables

\begin{tabular}{lcccccc}
\hline & CAR & EPS & PER & CR & ROE & DPR \\
\hline Mean & 0.043 & 397.138 & 14.986 & 94.393 & 25.767 & 35.937 \\
Maximum & 0.612 & 3048.221 & 43.175 & 438.227 & 89.908 & 82.950 \\
Minimum & -1.148 & -1185.270 & 0.509 & -167.307 & -20.389 & -3.435 \\
Std. Dev. & 0.300 & 633.651 & 8.338 & 102.148 & 26.634 & 17.602 \\
\hline
\end{tabular}

Source: Processed data, 2021

Table 3. Normality Test Results

\begin{tabular}{cc}
\hline Jarque Bera & 2,088 \\
\hline Probabilitas & 0,352 \\
\hline
\end{tabular}

Source: Processed data, 2021

The data normality test is used to determine whether the data in one particular variable is normally distributed or not by using the Jarque Bera test. The residual is declared normal if the probability of the Jarque Bera test is greater than the level of significance (alpha). Table 3 shows the results of normality analysis done on CAR, EPS, PER, CR, ROE and DPR variables, where each variable shows a significance value.

Table 3 shows the normality assumption test use Jarque Bera test statistic of 2.088 with a probability of 0.352 . These significance values are greater than the level of significance $(\alpha=5 \%)$. This means the residuals are normally distributed and of the normality assumption is fulfilled.

The multicollinearity test is used to find a correlation between independent variables. The significant correlation between the independent variables shows a multicollinearity problem. Table 4 shows the results of the Multicollinearity Test.

Table 4 above shows that the VIF value of all independent variables (EPS, PER, CR, ROE and DPR) is below 10. There is no multicollinearity of independent variables in this study.

The next step is heteroscedasticity test to determine the inequality of variance from residuals for one observation to another. A good regression model has a variance equation from residuals for one observation to another (homoscedasticity). Heteroscedasticity assumption test can be seen from White Test. Table 5 showed the results of heteroscedasticity tests. 
Table 5 shows the $0 b s * \mathrm{R}^{2}$ value is 8.941 at the probability of 0.069 . These results indicate that probability > level of significance (level $\alpha=5 \%$ ). It means the residuals have a homogeneous variety; thus, the assumption of heteroscedasticity is fulfilled.

The autocorrelation test determines the correlation of residual observations. The autocorrelation assumption test should not correlate. Table 6 shows the autocorrelation assumption test can be seen through the Lagrange Multiplier Test (Breusch-Godfrey). Table 6 shows the autocorrelation assumption using the Lagrange Multiplier Test (BreuschGodfrey) produce an Obs* R2 value of 1.553 with a probability of 0.980 . It can be stated that residual observations are not correlated, so the autocorrelation assumption is fulfilled.

The Lagrange Multiplier (LM) test is used to determine the Random Effect Model (REM) model is better than the Common Effect Model (CEM) model. The LM test is based on a chi-square distribution with a degree of freedom equal to the number of independent variables. The test criteria state that if the probability> level of significance ( $\alpha=5 \%)$ then HO is accepted, meaning that the effect in the panel regression estimation model used is CEM. Conversely, if the probability <level of significance ( $\alpha=5 \%$ ) then HO is rejected, meaning that the effect in the panel regression estimation model that is under the empirical data is REM. Table 7 the results of the LM test.

Table 7 shows the LM statistic is 0.933 with a probability of 0.334 . These results indicate the probability > level of significance $(\alpha=5 \%)$. The panel regression estimation model for EPS, PER, CR, ROE and DPR to CAR based on the LM test is CEM.

The Chow test is used to determine individual effects of the panel regression estimation model, whether the estimation model uses the Common Effect Model (CEM) or uses the Fixed Effect Model (FEM). The test criterion states that if the chi-square test statistic is <level of significance $(\alpha=$ $5 \%$ ) then $\mathrm{HO}$ is rejected, it means the effect in the panel regression estimation model used in FEM. Conversely, if the probability $\geq$ level of significance $(\alpha=$ $5 \%$ ) then $\mathrm{HO}$ is accepted, it means the effect in the panel regression estimation model that is in accordance with the empirical data is CEM. Table 8 the results of the Chow test can.

Table 8 shows that the chi-square test statistic in the Chow test for the effects of EPS, PER, CR, ROE and DPR on CAR is 3.107 with a probability of 0.540. This the panel regression estimation model for the effect of EPS, PER, CR, ROE and DPR on CAR is CEM. Based on two tests, namely the LM test and Chow test, the appropriate model for the effect of EPS, PER, CR, ROE and DPR on CAR is CEM. 
Table 4. Multicollinearity Test Results

\begin{tabular}{ccc}
$\begin{array}{c}\text { Independent } \\
\text { Variable }\end{array}$ & VIF & Description \\
\hline EPS & 1,125 & There is no multicollinearity \\
PER & 2,575 & There is no multicollinearity \\
CR & 1,586 & There is no multicollinearity \\
ROE & 2,676 & There is no multicollinearity \\
DPR & 1,333 & \\
\hline
\end{tabular}

Source: Processed data, 2021

Table 5. Heteroscedasticity Assumption Test

\begin{tabular}{cc}
\hline Obs*R-squared & 8,941 \\
\hline Probability & 0,069 \\
\hline
\end{tabular}

Source: processed by researchers, 2020

Table 6. Autocorrelation Assumption Test Lagrange Multiplier Test (Breusch-Godfrey)

\begin{tabular}{cc}
\hline $\mathrm{Obs}^{*} \mathrm{R}-\mathrm{squared}$ & 1.553 \\
\hline Probability & 0.980 \\
\hline Source: Processed by researchers, $\mathbf{2 0 2 0}$
\end{tabular}

Table 7. Lagrange Multiplier (LM) test

\begin{tabular}{ll}
\hline LM Statistics & 0.933 \\
\hline Probability & 0.334 \\
\hline
\end{tabular}

Source: Processed by researchers, 2020

Table 8. Chow Test (Cross-section Chi-square)

\begin{tabular}{ccc}
\hline Effect Test & Statistic & Prob. \\
\hline Cross-Section Chi-square & 3.107 & 0.540 \\
\hline
\end{tabular}

Source: Processed by researchers, 2020

\section{Hypotheses test}

Based on the two tests are LM test and the Chow test, the appropriate model for the effect of EPS, PER, CR, ROE and DPR on CAR is CEM. Table 9 the test results for the effect of EPS, PER, CR, ROE and DPR on CAR. Table 9 shows that partial hypothesis testing results of EPS to CAR produce a t-value of 3.019 with a probability of 0.004 smaller than $\alpha(0.05)$. This shows a significant effect of EPS on CAR. Therefore, H1.A hypothesis is accepted. The partial hypothesis testing for PER to CAR produces t-value of 1.937 with a probability of 0.059 greater than $\alpha(0.05)$. This shows that PER has no significant effect on CAR. It means H1.B hypothesis is accepted. 
Yayuk S. Rahayu: The Effect of Financial Performance and Dividend Policy

Table 9. Test results

\begin{tabular}{ccccc}
\hline Variables & Coefficient & Std Error & t-Statistic & Prob. \\
\hline EPS & 0.000 & $6.76 \times 10^{-05}$ & 3.019 & 0.004 \\
PER & 0.015 & 0.008 & 1.937 & 0.059 \\
CR & -0.000 & 0.000 & -0.863 & 0.393 \\
ROE & -0.003 & 0.002 & -1.414 & 0.164 \\
DPR & 0.002 & 0.003 & 0.605 & 0.548 \\
Constant & -0.190 & 0.120 & -1.579 & 0.121 \\
\hline F-statistic & $=2.292$ & R-squared $=0.207$ & & \\
Prob. & $=0.618$ Adj. R-squared $=0.116$ & & \\
\hline
\end{tabular}

Source: Processed by researchers, 2020

The partial hypothesis testing for CR on CAR produces t-count value of -0.863 with a probability of 0.393 greater than $\alpha(0.05)$. This shows that CR has no significant effect on CAR. Therefore, H1.C hypothesis is rejected. The partial hypothesis testing for ROE on CAR produces t-value of -1.414 with a probability of 0.164 greater than $\alpha(0.05)$. This shows that ROE has no significant effect on CAR. Therefore, H1.D hypothesis is rejected. The partial hypothesis testing for DPR on CAR produces t-value of -1.579 with a probability of 0.121 greater than $\alpha(0.05)$. This shows that DPR has no significant effect on CAR. This $\mathrm{H} 2$ the hypothesis is rejected.

\section{Determination Coefficient Testing}

The contribution of EPS, PER, CR, ROE and DPR to CAR can be seen through the coefficient of determination (R-squared) at 0.207 or $20.7 \%$. This means that variability of the CAR variable can be explained by variables EPS, PER, CR, ROE and DPR at 20.7\%. In other words, the contribution of EPS, PER, CR, ROE and DPR to CAR is $20.7 \%$, while the rest $79.3 \%$ is a contribution from other variables which are not discussed in this study.

\section{DISCUSSION}

\section{Effect of Earning Per Share (EPS) on Abnormal Return}

Earnings Per Share (EPS) is part of the growth ratio. According to (Kasmir, 2016), the ratio of earnings per share or book value ratio is a ratio to measure the success of management in achieving profits for shareholders. The analysis results show that EPS partially affects CAR. This shows that 5 companies sampled in this study can share their net profits with shareholders. Therefore, more companies provide benefits to shareholders will make more investors invest in companies in the Islamic capital market. In addition, investors motive to invest in the Islamic capital market are motivated is to get the maximum earning. High EPS reflects the income that will be received by shareholders on each share. More income received by 
investors will attract investors to invest in companies listed in the Islamic capital market, so the demand for company shares will increases. Higher stocks will increase the stock prices and return earned by investors.

The results of this study are inconsistent with research (Rahmawati, 2017) which states that EPS has no significant effect on stock returns but supports research conducted by (Mayuni \& Suarjaya, 2018) which states that EPS has a significant effect on stock returns.

\section{Effect of Price Earnings Ratio (PER) on Abnormal Return}

Price Earnings Ratio is part of the market ratio. According to (Herlianto, 2013) PER describes market appreciation of a company's ability to generate revenue. PER is used to measure market operations for the issuer's ability to generate profits. This shows the increase in PER value will not have an impact on increase the CAR of 5 sample companies in the Islamic capital market. In addition, PER is more related to other factors outside of stock returns, one of them is the investor's behavior of profit-taking when stock prices show an increase or decrease. This is due to uncertain economic and political conditions, and the sentimentality of the stock market itself.

The results of this study do not support earlier research (Ginting, 2013) which states that PER has a significant effect on stock returns but it is consistent with research conducted by (Roslita \& Kurniawan, 2017) which states that PER has no significant effect on stock returns.

\section{Effect of Current Ratio (CR) on Abnormal Return}

The Current Ratio is part of the liquidity ratio. According to (Kasmir, 2016) CR is a ratio that measures a company's ability to pay short-term obligations. Analysis results show that partially CR has no significant effect on CAR. This is due to the high liquidity of the company. The high CR is not necessarily good because it can show that many company funds in the Islamic capital market are unemployed (small company activity). This can reduce the company's ability and effect of company's poor performance and prospects in investors eyes. High CR also does not necessarily produce a high stock return to indicates that availability of current assets to pay off current liabilities in the company is also high. In addition, CR cannot attract investors' attention to investing in Islamic stocks. CR does not affect the rise of Islamic stocks. Investors pay less attention to CR, because CR is a company's ability to meet its short-term obligations, while investors invest in a long-term aspect.

The results of this study are different from previous research conducted (Miranti et al., 2019) which states that CR has a significant effect on Return. While the results of this study support research from (Wartono, 
2018) which states that CR does not have a significant effect on Abnormal Stock Returns.

\section{Effect of Return on Equity (ROE) on Abnormal Return}

Return on Equity is part of the profitability ratio. According to (Kasmir, 2016) ROE is a ratio used to measure net profit after tax with own capital. Analysis results show that partially ROE does not affect CAR. This means that ROE cannot attract investors' attention to invest in Islamic stocks, so it does not affect the rise of Islamic stocks. The insignificance of ROE indicates that the company cannot guarantee its equity with profit. In addition, ROE does not affect stock returns; it can be caused by a lower view of investors on the company's ability in the Islamic capital market to manage capital. The ROE has a negative response by shareholders because the data distribution pattern of stock returns tends to decrease when the ROE of a company increases.

The results of this study are not in line with research conducted (Ulfah \& Paramu, 2017) which states that ROE does not have a significant effect on Abnormal Return, but it is under research conducted by (Permana, 2017).

\section{Effect of Dividend Payout Ratio (DPR) on Abnormal Return}

The dividend Payout Ratio is part of the activity ratio (market value). DPR according to (Sudana, 2015) is a ratio that shows the percentage of the company's net income to be paid to shareholders in the form of dividends. Analysis results show that partially the DPR has no significant effect on CAR. This means that DPR is not a differentiator of CAR magnitude. DPR is not the determining variable to affects the company's CAR. The insignificance of DPR can be caused by the distribution of dividends to shareholders is too low to affect the percentage level of DPR. In addition, greater the dividends paid to Islamic shareholders need more cash to pay dividends. It makes the company's retained earnings will be smaller. This can reduce the company's opportunity to invest, so that company's growth can be hampered. If the company level has a small growth rate, investors will consider investing in the company. Investors consider this as negative information from a company, so the shares in the Islamic capital market are less desirable. As a result of this information, the share price in the Islamic capital market will decrease. If the stock price falls, the company's stock return will also decrease.

The results of this study are not in line with research conducted by (Carlo, 2014) which states that the DPR has a positive effect on stock returns but supports research conducted by (Ulfah \& Paramu, 2017) which states that the DPR has no significant effect on Abnormal Stock Returns. Islam has 
the principle of justice and prosperity, both property and profits must be distributed equally, as stated in Al-Qur'an surah al-Hasyr verse 7 which means:

"Any booty (fai-i) that Allah gave to His Messenger (from the property) that came from inhabitants of cities. Then it is for Allah, for apostles, relatives, orphans, poor people, and people those who are on way, so that treasure may not be circulated among the rich among you. what Apostle gave you, then accept it. leave what he forbids. and fear Allah. Indeed, Allah is very harsh in punishment " (al-Hashr: 7)

Islam determines that property, in essence, belongs to Allah Almighty. However, Allah has handed over His power over these assets to humans, he is given the authority to use and develop them. When a person has property, in essence, the property only to be used and developed especially for profit.

\section{CONCLUSION AND SUGGESTION}

This study aims to determine the effect of financial performance proxied by EPS, PER, CR \& ROE, and dividend policy proxied by DPR on CAR at companies listed at Jakarta Islamic Index (JII). Based on research results, it can be concluded that EPS influences the CAR of stocks which indicates that higher EPS will increase the CAR. Meanwhile, PER, CR \& ROE have no effect on CAR for stocks; it means that the increase of these three variables cannot increase the CAR. In addition, DPR also does not affect CAR of shares; it means that higher DPR cannot increase the CAR. Based on the results of the research above, the advice given should be concerned by future researchers. Future researchers should examine the research object other than Islamic companies in Jakarta Islamic Index (JII) because the Islamic stock index on Indonesia Stock Exchange is not only JII. In addition, further researchers should use other variables and latest research period, and more research samples to obtain better research results. The company should maintain and improve the company performance. The dividends distributed to shareholders should be increased to give investors the confidence to increase their investment. It is to increase the company's share price and have an impact on a high rate of return for shareholders. Investors should consider the EPS ratio, because of the significant effect of these variables on CAR.

\section{REFERENCES}

Bakar, N. A., \& Rosbi, S. (2019). New Approach of Calculation for Malaysia Shariah Composite Index. Researchgate.Net, April.

Carlo, M. A. (2014). Pengaruh Return on Equity, Dividend Payout Ratio, Dan Price To Earnings Ratio Pada Return Saham. E-Jurnal Akuntansi Universitas Udayana, 7(1), 150-164. 
Darsono, \& Ashari. (2005). Pedoman Praktis Memahami Laporan Keuangan. ANDI.

Fahmi, I. (2012). Manajemen Investasi, Teori dan Soal Jawab. Salemba Empat.

Ginting, S. and E. (2013). Analisis Faktor-Faltor Yang Mempengaruhi Return Saham Pada Perusahaan Manufaktur Yang Terdaftar Di Bursa Efek Indonesia. Jurnal Wira Ekonomi Mikroskil, 3, 31-39.

Herlianto, D. (2013). Manajemen Investasi Plus Jurus Mendeteksi Investasi Bodong (Pertama). Gosyen Publishing.

Horne, J. C. Van. (1994). Investasi dan Manajemen Portofolio (M. Sinaga (ed.); Jilid Dua). Erlangga.

Jogiyanto, M. H. (2010). Teori Portofolio dan Analisis Investasi (Ketujuh). BPFE Universtias Gajah Mada.

Jumingan. (2006). Analisis Laporan Keuangan. PT Bumi Aksara.

Kasmir. (2016). Analisis Laporan Keuangan. Raja Grafindo Persada.

Mayuni, I. A. I., \& Suarjaya, G. (2018). Pengaruh Roa, Firm Size, Eps, Dan Per Terhadap Return Saham Pada Sektor Manufaktur di BEI. E-Jurnal Manajemen Universitas Udayana, 7(8).

Miranti, D., Agustina, N., \& Azhar, Z. (2019). Pengaruh Current Ratio, Debt To Equity Ratio, Dan Total Asset Turnover Terhadap Return On Asset Pada Perusahaan Manufaktur Sektor Industri Barang Konsumsi Yang Terdaftar Di Bursa Efek Indonesia Periode 2012-2016. 4(4).

Parwati, R. R. A. D., \& Sudiartha, G. M. (2016). Pengaruh Profitabilitas, Leverage, Likuiditas Dan Penilaian Pasar Terhadap Return Saham Pada Perusahaan Manufaktur. 5(1), 385-413.

Permana, S. J. (2017). Analisis Faktor-Faktor Yang Memengaruhi Abnormal Return Saham Pada Perusahaan Perbankan Dan Asuransi Yang Terdaftar Di Bursa Efek Indonesia. Bisma, 11(1), 12-27.

Prastowo, D., \& Yuliati, R. (2005). Analisis Laporan Keuangan Konsep dan Aplikasi. UPP AMP YKPN.

Rahmawati, A. (2017). Pengaruh Earning Per Share (EPS) Return On Equity (ROE) Dan Debt To Equity Ratio (DER) Terhadap Return Saham Pada Perusahaan Food And Beverages Yang Terdaftar Di Bursa Efek Indonesia Periode 2011-2015. Jurnal Online Mahasiswa, 2(2).

Roslita, E. and Kurniawan, N. (2017). Pengaruh Manajemen Laba, IOS, ROA, NPM dan PER Terhadap Return Saham Perusahaan Manufaktur. Journal Esensi, 20(1), 96-106.

Samsuar, T. (2017). Pengaruh Faktor Fundamental dan Teknikal Terhadap Harga Saham Industri Perhotelan yang Terdaftar di Bursa Efek Indonesia. Jurnal Ekonomi, Keuangan Dan Perbankan Syariah, 1(1), 116131.

Sasongko, N., \& Wulandari, N. (2006). Pengaruh EVA dan Rasio-rasio Profitabilitas Terhadap Harga Saham. Jurnal Akuntansi Dan Keuangan, 19(1), 64-80.

Sudana, I. M. (2015). Manajemen Keuangan Perusahaan (Kedua). Erlangga.

Sujarweni. (2017). Analisis Laporan Keuangan Teori, Aplikasi dan Hasil Penelitian. Pustaka Baru Press.

Sutrisno. (2009). Manajemen Keuangan Teori, Konsep dan Aplikasi. Ekonosia. 
Tandelilin, E. (2010). Investasi dan Manajemen Portofolio. Kanisius.

Ulfah, D. F., \& Paramu, H. (2017). Pengaruh Kinerja Keuangan Dan Kebijakan Dividen Terhadap Abnormal Return. Jurnal Sains Manajemen Dan Bisnis Indonesia, 7(1), 58-76.

Utami, F. and Murwaningsari, E. (2017). Analisis Pengaruh Rasio Profitabilitas Terhadap Return Saham Dengan Kebijakan Dividen Sebagai Variabel Moderasi Studi Empiris Pada Perusahaan Manufaktur Di Bursa Efek Indonesia Periode 2012-2015. Jurnal Magister Akuntasi Trisakti (e-Journal), 4(1), 75-94.

Wartono, T. (2018). Pengaruh Current Ratio (Cr) Dan Debt To Equity Ratio (Der) Terhadap Return On Asset (Roa). Jurnal Kreatif, 6(2), 79-97.

Yuliawati, Y., \& Darmawan, D. (2019). Rasio Keuangan dan Pengaruhnya Terhadap Harga Saham Syariah dengan Price Earning Ratio Sebagai Variabel Moderasi. Al-Tijary, 4(2), 109-124. 